\title{
Reflexives and reflexive constructions in Afrikaans
}

\author{
Johan Oosthuizen \\ Department of General Linguistics, Stellenbosch University, South Africa \\ E-mail: jo@sun.ac.za
}

\begin{abstract}
This article provides a non-formalistic description of the various reflexive pronouns in Afrikaans. In addition to the traditional class of reflexive pronouns, it is shown that possessive pronouns can also be used reflexively. The facts about (obligatory) reflexivity involving these two types of pronoun are illustrated with reference to several types of construction in which they can occur. It is moreover shown that, besides the subject, the reflexive can take as its antecedent an expression functioning as the direct object, indirect object or as a prepositional object. Attention is also given to a number of non-reflexive constructions, that is, constructions containing inherently non-reflexive verbs and prepositions which disallow a coreferential relationship between the pronoun and some other expression in the sentence.
\end{abstract}

Keywords: reflexives, Afrikaans, pronouns, reflexivity

\section{Introductory remarks}

This article provides a largely non-formalistic description of the various reflexive pronouns in Afrikaans and the constructions in which they can occur; these represent some of the facts that have to be accounted for by a proper syntactic theory of reflexivity. ${ }^{1}$

Before proceeding, a few remarks are in order about the terms "construction" and "reflexive construction". The term "construction" is used here in an informal, non-technical way, in line with the following comments by Chomsky (1995: 170):

The notion of grammatical construction is eliminated [in minimalist syntax], and with it, construction-particular rules. Constructions such as verb phrase, relative clause, and passive remain only as taxonomic artefacts, collections of phenomena explained through the interaction of the principles of UG, with the values of parameters fixed.

\footnotetext{
${ }^{1}$ Cf. Oosthuizen (2013a, 2013b) for an attempt to develop a theory of (obligatory) reflexivity within the framework of minimalist syntax.
} 
The term "reflexive construction" is similarly used in a non-technical way as a convenient label to refer to a collection of phenomena involving the syntactic distribution of reflexives (cf. also Rizzi 2012: 3). Moreover, describing a particular construction as "reflexive" when it contains a reflexive pronoun, does not necessarily entail that it cannot also be used with a non-reflexive pronoun, as will be illustrated below.

\section{Reflexives}

Afrikaans items belonging to the traditional lexical category of reflexives (or reflexive pronouns) come in two forms: ${ }^{2}$ (i) morphologically simplex forms that are indistinguishable from personal pronouns displaying accusative case, and (ii) morphologically complex forms where the pronoun takes the suffix - self. $^{3}$ The various forms are shown in the following table.

Table 1: Reflexive pronouns in Afrikaans

\begin{tabular}{|c|c|c|c|c|c|}
\hline Person & Number & Gender & Simplex & Complex & Formal \\
\hline 1 & $\mathrm{SG}^{4}$ & - & my & myself & - \\
\hline 1 & $\mathrm{PL}$ & - & ons & onsself & - \\
\hline 2 & $\mathrm{SG}$ & - & jou & jouself & u/uself \\
\hline 2 & $\mathrm{PL}$ & - & julle/jul & julleself/julself & u/uself \\
\hline 3 & $\mathrm{SG}$ & $\mathrm{M} / \mathrm{N}$ & hom & homself & - \\
\hline 3 & $\mathrm{SG}$ & $\mathrm{F}$ & haar & haarself & - \\
\hline & $\mathrm{PL}$ & $\mathrm{M} / \mathrm{F} / \mathrm{N}$ & hulle/hul & hulleself/hulself & - \\
\hline
\end{tabular}

${ }^{2}$ The qualification "traditional" is important here. A core assumption of the analysis of obligatory reflexivity proposed in Oosthuizen (2013a: ch. 3; 2013b) is that "reflexive (pronoun)" is not a basic lexical category, but that reflexive and non-reflexive pronouns are syntactically derived from the same lexical root pronoun $\sqrt{ }$ PRON. The difference between these two types of pronoun is thus described in syntactic rather than lexical terms (cf. e.g. Zwart 2002; Heinat 2006a, b). Ponelis (1979: 86) also states that reflexives do not form a distinct class, but that they represent a particular use of personal pronouns in the accusative form. Section 4 of this article will illustrate that possessive pronouns - i.e. pronouns with genitive case - can also be used as reflexives.

${ }^{3}$ The form self can also be used as a separate word, as in the examples in (i). As these examples show, self functions as an anaphor in such cases in that it must enter into a coreferential relationship with some other expression in the sentence. (For the sake of convenience, (non-)coreferential relationships are indicated by (non-)identical subscripts.)

(i) a. $\mathrm{Ek}_{\mathrm{i}}$ self $_{\mathrm{i}}$ het die meisie ${ }_{\mathrm{j}}$ gesien.

I self has the girl seen

"I myself saw the girl"

b. Self $f_{i}$ het $e_{k_{i}}$ die $_{\text {meisie }}$ gesien.

c. $\mathrm{Ek}_{\mathrm{i}}$ het self $\mathrm{d}_{\mathrm{i}}$ die meisie $_{\mathrm{j}}$ gesien.

d. $E_{\mathrm{i}}$ het die meisie $\mathrm{j}_{\mathrm{j}} \mathrm{self}_{\mathrm{i}} /$ self $_{\mathrm{j}}$ gesien.

The syntax and semantic interpretation of self and other similar expressions will not be examined in this article.

${ }^{4} \mathrm{SG}=$ singular, $\mathrm{PL}=$ plural, $\mathrm{M}=$ masculine, $\mathrm{F}=$ feminine, $\mathrm{N}=$ neuter . 
In older varieties, and also some present-day varieties like those spoken in the north-western parts of South Africa, the suffix -self can take the form -selwers. Sig and sigself/sigselwers (third-person forms lacking a gender specification) also occur, but are mainly associated with older varieties. Current use of the reflexive $\operatorname{sig}($ self) is occasionally found when the standard third-person masculine form hom is deliberately avoided in contexts where the reflexive takes as its antecedent an expression which is unspecified for gender, as illustrated in (1).

a. Die gedig $g_{\mathrm{i}}$ leen sig(self) $)_{\mathrm{i}}$ tot verskeie interpretasies.

the poem lends itself to several interpretations

"The poem lends itself to several interpretations"

b. Die Vroueliga $a_{i}$ distansieer sig(self $)_{i}$ van enige vorm van diskriminasie. the women-league distances itself from any form of discrimination "The Women's League dissociates itself from any form of discrimination"

Although Afrikaans has a third-person singular neuter pronoun, dit ("it"), this form cannot be used as a reflexive as illustrated by the unacceptability of the examples in (2); in these cases, the standard form of the reflexive is hom.
a. $\quad *$ Die hond ${ }_{\mathrm{i}}$ het $\operatorname{dit}(\text { self })_{\mathrm{i}}$ hees geblaf. the dog has it(self) hoarse barked
b. * Die storm ${ }_{i}$ sal dit(self) $)_{i}$ uitwoed. the storm will it(self) spend
c. (Ek onthou daardie toneel.) *Dit het dit(self) afgespeel in die kerk.
(I remember that scene.) it has it(self) out-played in the church

Interestingly, in some styles, vocative items which are integrated into sentence structure can be used in place of reflexives, as shown in (3) below (cf. Ponelis 1979: 37-40, 65, 229). Such items - which serve to express a range of feelings and relationships, e.g. endearment, friendship, family relation, politeness, respect, anger, scorn, etc. - include titles (Mevrou ("Madam"), Dokter ("Doctor"), Professor); names of people and pets (Jan, Pluto); and family terms (pappa ("daddy"), tannie ("aunt"), oom ("uncle"), neef ("nephew")). As illustrated in (4), vocative items that are used reflexively can also occur with the suffix - self, although this does not seem to be common (cf. note 10 below).

(3) a. Mamma ${ }_{i}$ het vir Mamma ${ }_{i}$ heeltemal misgis met die tyd.

Mommy has for Mommy completely misjudge with the time

"Mommy completely misjudged herself with the time"

b. Dokter ${ }_{i}$ sal vir Dokter ${ }_{i}$ 'n nuwe kar moet koop.

Doctor will for Doctor a new car must buy

"You should buy yourself a new car, Doctor"

(4) a. Pa moenie vir Pa-self $f_{i}$ seermaak nie!

Dad must-not for Dad-self hurt NEG

"Dad, you mustn't hurt yourself!"

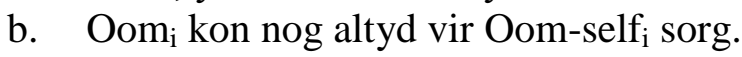

uncle could still always for uncle-self care

"You have always been able to look after yourself, Uncle" 


\section{Reflexive constructions}

\subsection{Verbal object constructions}

Several constructions in Afrikaans can be informally described as "reflexive" in the sense that they contain pronominal forms (i) which are not (and sometimes cannot be) used on their own to identify a referent, and (ii) which are (and sometimes have to be) interpreted reflexively (or, in broader terms, anaphorically). One such construction is illustrated by the examples in (5); in each case, the pronoun obligatorily enters into a coreferential relationship with the subject of the sentence.

a. Die vrou ontferm haar $_{\mathrm{i}} / *$ haar $_{\mathrm{j}}$ oor die kinders.

the woman pities her over the children

"The woman takes pity on the children"

b. $\operatorname{Jan}_{\mathrm{i}}$ het $\mathrm{hom}_{\mathrm{i}} / * \mathrm{hom}_{\mathrm{j}}$ verset teen die aanval.

Jan has him resist against the attack

"Jan resisted the attack"

c. Die seuns moet hulle $_{\mathrm{i}} /$ *hulle $_{\mathrm{j}}$ gedra.

the boys must them behave

"The boys must behave themselves"

The verbs in (5a-c) belong to the class of "inherently reflexive" verbs. These are verbs which are semantically intransitive in that they lack a complement functioning as an argument, yet at the same time are syntactically transitive in that they select a reflexive as their complement. ${ }^{5}$ With these verbs the reflexive is standardly used without the -self suffix, although - self forms are commonly found in everyday speech and often also in written texts. ${ }^{6}$

Since the reflexive complement selected by an inherently reflexive verb does not function as an argument - in Büring's (2005: 22) words, it is "semantically inert" - it cannot be replaced with a full nominal expression. This is illustrated by the unacceptability of the example in

\footnotetext{
5 Büring (2005: 22) states that inherently reflexive verbs "are semantically intransitive, but syntactically transitive, and show a - presumably uninterpreted - reflexive as the semantically 'inert' argument." Some more examples of inherently reflexive verbs in Afrikaans are afsloof ("work like a slave, wear out"), beywer ("endeavour, do one's best"), indink ("imagine"), misgis ("misjudge"), ooreet ("overeat"), skaam ("be ashamed of"), verbeel ("fancy, imagine"), vergaap ("be amazed by"), verset ("resist") and verspreek ("speak incorrectly, make a slip of the tongue"); cf. Ponelis (1979: 227-230) and also note 6.

6 Ponelis (1979: 83, 88) ascribes the increasing use of the -self form of the reflexive, particularly in utterances with inherently reflexive verbs, to the influence of English. (Interestingly, though, a similar spread of the -self form is found in the diachrony of English; cf. e.g. Keenan (2009).) When utterances like those in (5) are spoken with the normal, non-emphatic sentence stress pattern, the verb standardly receives the primary stress (cf. Jan verSET hom). However, when the complex form of the reflexive is used, the utterance can apparently also be spoken with the primary stress on -self (cf. Jan verset homSELF). Generalising the claim made by Ponelis (1979: 81-83; cf. note 10 below), it is likely that -self is used in such cases to provide emphasis, specifically, to turn the pronoun into an emphatic form. If this is true, it would be contrary to Büring's (2005) claim that "semantically inert arguments, as found with inherently reflexive verbs, cannot bear emphasis" (2005: 23) and show an "inability to be stressed" (2005: 22, note 20).
} 
(6b); that the verb requires a reflexive complement is shown by the difference in acceptability between $(6 a)$ and $(6 c){ }^{7}$
a. $\operatorname{Jan}_{\mathrm{i}}$ het hom $\mathrm{i}$ gedra.
Jan has him behave
"Jan behaved himself"
b. *Jan het die seun gedra. Jan has the boy behave
c. *Jan het gedra.

Some other characteristics of semantically inert reflexives are that they cannot be fronted and, as implied by (6b), cannot be coordinated or right-node raised in coordinate structures where one of the conjoined clauses contains a verb which is not inherently reflexive. ${ }^{8}$ These characteristics are illustrated by the unacceptability of the examples in (7). The reflexive has been fronted in the focalisation construction in (7a) and the passive construction in (7b), coordinated with another (pro)nominal expression in (7c), and right-node raised in $(7 \mathrm{~d})$.
a. $\quad * \mathrm{Hom}_{\mathrm{i}}$, het $\mathrm{Jan}_{\mathrm{i}}$ gedra. him has Jan behave
b. $\quad * \mathrm{Hom}_{\mathrm{i}}$ is gedra deur $\mathrm{Jan}_{\mathrm{i}}$. him was behaved by Jan
c. ${ }^{*} \mathrm{Jan}_{\mathrm{i}}$ gedra hom $\mathrm{i}$ en haar / Marie / die meisie. Jan behaves him and her / Marie / the girl
d. $\quad * J a_{i}$ gedra en Pieter ${ }_{j}$ haat homi. Jan behaves and Pieter hates him

Consider next the class of semantically transitive verbs in Afrikaans. This class includes three subclasses which, although not inherently reflexive, can all occur in reflexive constructions. One subclass comprises syntactically transitive verbs which can take both morphologically complex and simplex reflexives as their complement. The construction involving verbs of this subclass is illustrated by the examples in (8) and $(9) ;{ }^{9}$ notice that the simplex form of the pronoun can be interpreted reflexively as well as non-reflexively, whereas the -self form can

\footnotetext{
${ }^{7}$ Afrikaans has a small subclass of inherently reflexive verbs which can be used without a syntactic complement. One of these verbs is illustrated in (i); others include inmeng ("interfere"), ontpop ("turn out to be, emerge") and terugtrek ("withdraw, retire from").

(i) $\quad \operatorname{Jan}_{\mathrm{i}}$ het $\left(\mathrm{hom}_{\mathrm{i}}\right) / * \mathrm{hom}_{\mathrm{j}}$ verslaap.

Jan has him oversleep

"Jan overslept (himself)"

${ }^{8}$ Cf. Büring (2005: 22, note 20) for these characteristics of semantically inert reflexives. The term "right-node raising" refers to a syntactic operation associated with earlier versions of generative syntactic theory (cf. e.g. Postal 1974), and which serves to derive a coordinate structure like (ib) below from the underlying structure in (ia). The conjoined clauses in (ia) have identical expressions as their rightmost constituent. Right-node raising involves making a copy of these expressions, adjoining this copy to the right of the coordinate structure, and deleting the two identical expressions (indicated by means of strikethrough in (ib)).

(i) a. [[John bought the house] and [Mary renovated the house]]

b. [[John bought the house] and [Mary renovated the house]] the house

For more recent analyses of right-node raising phenomena, cf. e.g. Abels (2004) and Bošković (2004).

9 Some more examples of this subclass of semantically transitive verbs are keer ("stop, control"), vermoei ("exhaust, tire, wear out") and wegsteek ("hide"); cf. Ponelis (1979: 82-83, 87).
} 
only be interpreted reflexively. ${ }^{10}$ As illustrated by the unacceptability of the (b) sentences, these verbs cannot be used without a syntactic complement.

a. $\operatorname{Jan}_{\mathrm{i}}$ het homself $\mathrm{i} /$ hom $_{\mathrm{i}} / \mathrm{hom}_{\mathrm{j}}$ beseer.

Jan has himself / him hurt

"John hurt himself / him"

b. *Jan het beseer.
a. Marie kon haarself $_{\mathrm{i}} /$ haar $_{\mathrm{i}} /$ haar $_{\mathrm{j}}$ nie bedwing nie. Marie could herself / her not control NEG "Marie couldn't restrain herself / her"
b. *Marie kon nie bedwing nie.

The members of the second subclass of semantically transitive verbs can also take both morphologically complex and simplex reflexives as their syntactic complement. However, unlike verbs of the type illustrated in (8) and (9), the verbs of this second class do not require a syntactic complement. Consider the examples in (10) and (11). In the (a) sentences, the verb selects a pronoun as its syntactic complement; the -self form of the pronoun is interpreted as a reflexive, whereas the simplex form can be interpreted both reflexively and non-reflexively. When these verbs are used without a syntactic complement, as in the (b) examples, the interpretation is the same as that of the corresponding sentence containing a reflexive. ${ }^{11}$

(10) a. Jan skeer homself $_{\mathrm{i}} /$ hom $_{\mathrm{i}} /$ hom $_{\mathrm{j}}$ elke oggend.

Jan shaves himself / him every morning

"Jan shaves himself / him every morning"

b. Jan skeer elke oggend.

(11) a. Marie ${ }_{\mathrm{i}}$ het haarself $\mathrm{h}_{\mathrm{i}} /$ haar $_{\mathrm{i}} /$ haar $_{\mathrm{j}}$ na die venster toe gedraai.

Marie has herself / her towards the window to turned

"Marie turned herself / her towards the window"

b. Marie het na die venster toe gedraai.

\footnotetext{
${ }^{10}$ Ponelis (1979: 81-83) claims that - self serves to strengthen ("versterk") the pronoun - that is, to bring about an emphatic form of the pronoun - in utterances where the verb is not inherently reflexive (like those in (10)(12)). Cf. Büring (2005: 21-23) for the use of -self in English, and Reuland (2001) and Reuland and Everaert (2001: 654-660) for a discussion of the lexical and syntactic properties of morphologically simplex and complex reflexives in Dutch, English, German and Frisian. Heinat (2006a: 89-91) provides several arguments against the proposal by, amongst others, Reinhart and Reuland (1993) that the English morpheme self (and the corresponding morpheme in e.g. Swedish and Old English) functions as a reflexivizer. Like Ponelis (1979: 8183 ) in the case of Afrikaans, Heinat (2006a: 91) claims that "the 'self'-morpheme indicates emphasis and not reflexivity"; cf. also Büring (2005: 23). Zwart (2002: 273) argues that "anaphors can be analyzed as pronouns with added focus markers", where - self represents such a focus marker. This idea is central to the analysis of obligatory reflexivity proposed in Oosthuizen (2013a, 2013b).

${ }^{11}$ Other examples of this subclass of semantically transitive verbs in Afrikaans are aanmeld ("report"), aantrek ("dress"), losruk ("wrench free"), onttrek ("withdraw, recuse"), uittrek ("undress") and was ("wash").

According to Büring (2005: 22), verbs of this subclass "in English and cross-linguistically, very often describe typically self-directed actions such as acts of grooming (cf. English wash, shave); typically otherdirected actions such as seeing, beating, or killing are unlikely candidates to be expressed by (optionally) intransitive verbs, and require a transitive construction with a reflexive pronoun when used to describe a selfdirected event." These remarks hold for Afrikaans as well; cf. the examples in (14) and (15) below. It should be noted that the example in $(10 \mathrm{~b})$ could receive a non-reflexive interpretation in an appropriate context, for instance where Jan is a barber who shaves customers in the morning and cuts hair in the afternoon.
} 
Semantically transitive verbs of the third subclass are similar to those of the class illustrated in (10a) and (11a) in that they select a syntactic complement, which moreover can be in the form of a morphologically simplex or complex pronoun. As in all the previous cases, the complex form of the pronoun is obligatorily interpreted as a reflexive. However, in contrast to the other two subclasses, with verbs of this third class a morphologically simplex pronoun can only be interpreted non-reflexively, as illustrated by the examples in (12a) and (13a). ${ }^{12}$ That the verbs in question cannot be used without a syntactic complement is shown by the unacceptability of the (b) sentences. ${ }^{13}$
a. $\quad \operatorname{Jan}_{\mathrm{i}}$ haat homself $\mathrm{f} /$ hom $_{\mathrm{i}} /$ hom $_{\mathrm{j}}$. Jan hates himself / him "Jan hates himself / him"
b. *Jan haat.
a. $\quad$ Marie $_{\mathrm{i}}$ wil haarself $\mathrm{i} / *$ haar $_{\mathrm{i}} /$ haar $_{\mathrm{j}}$ nomineer as voorsitter. Marie wants-to herself / her nominate as chairperson "Marie wants to nominate herself / her as chairperson"
b. *Marie wil nomineer as voorsitter.

In contrast to the three subclasses of semantically transitive verbs which allow a reflexive interpretation for their pronominal complements, as illustrated in (8)-(13), there are at least two subclasses of "inherently non-reflexive" verbs, that is, verbs where the reflexive interpretation is normally disallowed. The first comprises verbs which express movement of one entity relative to another (usually also moving), with the former remaining in a position before, after or alongside the latter or changing from one of those positions to another. Some of the interpretations allowed and disallowed by verbs of this subclass are illustrated by the examples in (14). ${ }^{14}$ The verbs of the second subclass, illustrated by the examples in (15), express some sort of action by one entity on another, possibly involving physical contact, and causing the latter to move away from or towards the former. ${ }^{15}$ In both cases, the pronominal complement of the verb is interpreted non-reflexively. ${ }^{16}$

\footnotetext{
${ }^{12}$ More examples of this subclass of semantically transitive verbs are bewonder ("admire"), doodmaak ("kill"), herken ("recognise"), oortuig ("convince"), red ("save"), verkies ("prefer") and verwyder ("remove").

${ }^{13}$ In utterances like those in (8)-(13) - i.e. where a pronominal complement is selected by a verb that is not inherently reflexive - the primary stress is placed on the pronoun when the utterance is spoken with the normal,

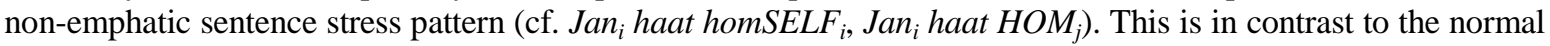
stress pattern which is standardly found with utterances containing an inherently reflexive verb (cf. note 6).

14 Some more examples of this subclass of verbs are agterlaat ("leave behind"), agternasit ("chase"), agtervolg ("pursue"), inhaal ("catch up"), lei ("lead"), opvolg ("succeed") and voorafgaan ("precede"). As the examples show, these verbs are typically compounds with a preposition (or adverb) expressing direction as their first element.

15 This subclass includes several compound verbs with a directional preposition or adverb as their first element, e.g. rondstamp ("push around"), terugstuur ("send back"), uitstuur ("send out") and wegpluk ("pull away").

${ }^{16}$ It was stated above that the two subclasses of verbs illustrated in (14) and (15) "normally" do not allow a reflexive interpretation for their pronominal complements. Given an appropriate context, however, such an interpretation would be feasible, for example, where the speaker is using the pronominal complement to refer to one or another representation or depiction (a statue, painting, cardboard cut-out, etc.) of the entity already identified by the subject of the sentence. Such an interpretation would be pragmatically highly constrained, and evidently cannot be accounted for in exclusively grammatical terms. The general point is well stated by Sperber and Wilson (1995: 9-13) who illustrate a wide range of aspects of interpretation which "involve an interaction between linguistic structure and non-linguistic information, only the former being dealt with by the grammar"
} 
(14) a. $\operatorname{Jan}_{\mathrm{i}}$ het $*$ homself $_{\mathrm{i}} /{ }^{*}$ hom $_{\mathrm{i}} /$ hom $_{\mathrm{j}}$ net voor die brug verbygesteek. Jan has himself / him just before the bridge by-passed "Jan overtook him just before the bridge"

b. Marie sal $_{\mathrm{i}}$ haarself $\mathrm{f}_{\mathrm{i}} /$ haar $_{\mathrm{i}} /$ haar $_{\mathrm{j}}$ na die funksie toe vergesel. Marie will herself / her to the function to accompany "Marie will accompany her to the function"

(15) a. Marie het $_{\mathrm{i}}^{*}$ haarself $_{\mathrm{i}} /$ *haar $_{\mathrm{i}} /$ haar $_{\mathrm{j}}$ omgestamp.

Marie has herself / her over-pushed

"Marie pushed her over"

b. $\operatorname{Jan}_{\mathrm{i}}$ wink $^{*}$ homself $_{\mathrm{i}} /$ *hom $_{\mathrm{i}} /$ hom $_{\mathrm{j}}$ nader.

Jan beckon himself / him near

"Jan beckoned him to come nearer"

In the constructions in (8)-(13), the pronoun functions as the direct object argument of a transitive verb and has the thematic $(\theta$-)role of theme (or patient). In the double object construction illustrated by the examples in (16), by contrast, the pronoun functions as the indirect object argument of a ditransitive verb and is assigned the $\theta$-role of goal. ${ }^{17}$ In this construction, the complex form of the pronoun is interpreted as a reflexive and the simplex form as a non-reflexive. ${ }^{18}$

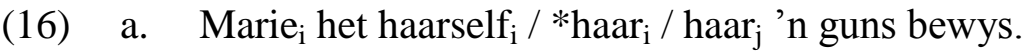

Marie has herself / her a favour proved

"Marie did herself / her a favour"

b. $\operatorname{Jan}_{\mathrm{i}}$ gun homself $_{\mathrm{i}} /{ }^{*} \mathrm{hom}_{\mathrm{i}} /$ hom $_{\mathrm{j}}$ geen rus nie.

Jan grants himself / him no rest NEG

"Jan doesn't allow himself / him any rest"

\subsection{Prepositional object constructions}

In all the constructions considered so far, the reflexive occurs either as the semantically inert syntactic complement of an inherently reflexive verb, as in (5) and (6), or as the (in)direct object argument of a (di)transitive verb, as in (8)-(13) and (16). The reflexive can, however, also occur as the object argument of a preposition, as shown by the examples in (17). In both cases, the preposition selects a morphologically complex or simplex pronoun as its complement; the -self form is interpreted reflexively and the simplex form non-reflexively. The pronoun is assigned the $\theta$-role of patient in (17a) and source in (17b). ${ }^{19}$

(Sperber and Wilson 1995: 10). Such interactions involving the interpretation of reflexives will not be dealt with in this article. For interesting proposals in this regard, cf. Culicover and Jackendoff (2005: ch. 10 and 11).

17 One of the $\theta$-roles which is sometimes identified in the literature is that of benefactive (or beneficiary). However, it is not always clear exactly how to differentiate this role from that of goal (cf. e.g. Haegeman 1994: 50). On intuitive grounds, it could be claimed that the role assigned to the indirect object argument in (16a) is actually benefactive and something like "malefactive" in the case of (16b).

${ }^{18}$ Some more examples of ditransitive verbs, i.e. verbs occurring in the double object construction, are belowe ("promise"), gee ("give, provide"), leer ("learn, teach"), ontsê ("deny"), toedien ("administer") and toeken ("award"); cf. Ponelis (1979: 206-207).

${ }^{19}$ Following what seems to be common practice in grammatical analyses, it is assumed in this article that the object argument of a preposition is assigned its particular $\theta$-role by the preposition in question. However, it is possible that the $\theta$-role is actually assigned by the verb (or the verb in conjunction with the preposition), especially in those cases where the containing PP functions as the complement of the verb rather than as an 


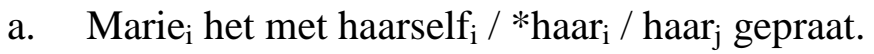

Marie has with herself / her talked

"Marie talked to herself / her"

b. $\operatorname{Jan}_{\mathrm{i}}$ het seker van homself $/$ * hom $_{\mathrm{i}} /$ hom $_{\mathrm{j}}$ 'n Valentynskaartjie gekry.

Jan has likely from himself / him a valentine-card got

"Jan probably received a Valentine's card from himself / him"

Different, and often less firm, patterns of acceptability than the one illustrated in (17) are found with prepositions that assign $\theta$-roles other than patient or source to their pronominal complement. Firstly, with a preposition assigning the agent $\theta$-role, the simplex form of the pronoun can be interpreted reflexively as well as non-reflexively, as shown in (18); in this case the reflexive is standardly used without the - self suffix. ${ }^{20}$

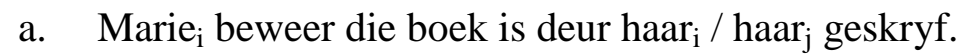

Marie claims the book was by her written

"Marie claims the book was written by her"

b. $\quad \operatorname{Jan}_{\mathrm{i}}$ sê daardie moontlikheid is deur hom / hom $_{\mathrm{j}}$ oorweeg.

Jan says that possibility was by him considered

"Jan says that possibility was considered by him"

Consider, secondly, constructions in which the preposition assigns the $\theta$-role of goal to its pronominal complement. In this case, there appear to be two patterns of acceptability. On the one hand, with verbs that typically imply (physical or abstract) movement away from the agent, the simplex form of the pronoun can only be interpreted non-reflexively, which means that the -self form is required for expressing reflexivity. This is illustrated by the examples in (19). On the other hand, with verbs that typically imply (physical or abstract) movement towards the agent, the -self form is not standardly used and the simplex form can have both a reflexive and a non-reflexive interpretation, as in (20). ${ }^{21}$

adjunct. Another possibility in such cases is that the $\theta$-role is not assigned specifically to the object of the preposition, but to the PP as a whole. These possibilities will not be examined further here.

${ }^{20}$ Given Ponelis's (1979) claim about the increasing use of the - self form of the reflexive in Afrikaans (cf. note 6 ), it could be argued that the use of this form in examples like (18) should be ascribed to the influence of English (although, interestingly, the -self form seems to be unacceptable in the corresponding English examples in (18)). Alternatively, it could be the case that -self is used in these examples to provide emphasis (cf. note 10), especially since the utterances in question can be spoken with the primary stress on -self (cf.

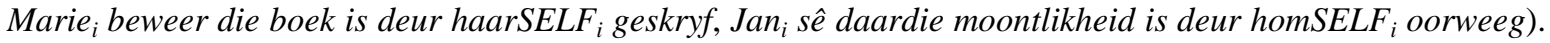
Unless otherwise stated, these remarks about the use of the complex form of the reflexive also apply to the examples in (20)-(22) and in note 21.

${ }^{21}$ In cases where the preposition appears to assign the benefactive $\theta$-role (cf. note 17) to its pronominal complement, as in (i) below, the pattern of acceptability is the same as that illustrated in (20).

(i) $\operatorname{Jan}_{\mathrm{i}}$ het vir homi $/$ hom $_{\mathrm{j}}$ 'n toebroodjie gemaak.

Jan has for him a sandwich made

"Jan made a sandwich for himself / him"

The pattern of acceptability in (20) is also found with prepositions like om ("around"), onder ("under") and oor ("over"), as illustrated by the examples in (ii) below. In each case, the preposition assigns some sort of goal $\theta$-role to its pronominal complement. Unlike in (20), however, the activities expressed by the verbs in (ii) do not seem to involve (physical or abstract) displacement of the theme, but rather a three-dimensional change or "deformation".

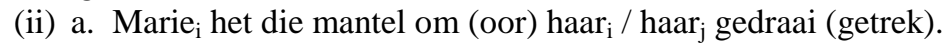

Marie has the cloak around (over) her twisted (pulled)

"Marie pulled the cloak around (over) her" 
(19) a. $\operatorname{Jan}_{\mathrm{i}}$ het die Valentynskaartjie vir homself $/$ / hom $_{\mathrm{i}} /$ hom $_{\mathrm{j}}$ gestuur.

Jan has the Valentine-card for himself / him sent

"Jan sent the Valentine's card to himself / him"

b. Marie $\mathrm{i}_{\mathrm{i}}$ kon die aandele aan haarself $\mathrm{f}_{\mathrm{i}} /$ haar $_{\mathrm{i}} /$ haar $_{\mathrm{j}}$ verkoop het.

Marie could the shares to herself / her sold have

"Marie could have sold the shares to herself / her"

(20) a. Marie ${ }_{i}$ het vir haar ${ }_{i} /$ haar $_{j}$ koffie bestel.

Marie has for her coffee ordered

"Marie ordered coffee for herself / her"

b. $\operatorname{Jan}_{\mathrm{i}}$ wil 'n motorfiets vir hom $\mathrm{i} /$ hom $_{\mathrm{j}}$ koop.

Jan wants-to a motorcycle for him buy

"Jan wants to buy a motorcycle for himself / him"

Consider next constructions where the preposition assigns the $\theta$-role of (physical or abstract) location to its pronominal object. As illustrated by the examples in (21), the general pattern in these constructions is that the simplex form of the pronoun can be interpreted both reflexively and non-reflexively; the morphologically complex form is not standardly used.

(21) a. Marie sit die boek langs haar $_{i} /$ haar $_{j}$ neer.

Marie puts the book next-to her down

"Marie puts the book down next to her"

b. $\operatorname{Jan}_{\mathrm{i}}$ het baie wagte om hom $\mathrm{i} /$ hom $_{\mathrm{j}}$ geplaas.

Jan has many guards around him placed

"Jan placed many guards around him"

The pattern illustrated in (21) does not hold, however, for constructions where the preposition assigns a $\theta$-role of what may be called "subject-associated (physical or abstract) location" to its pronominal complement. In this case, as in the case of inherently reflexive verbs (cf. (5) and (6) above), the pronoun cannot receive a non-reflexive interpretation. This is clear from the examples in (22); the reflexive standardly takes the morphologically simplex form.

(22) a. Marie kry 'n snaakse gevoel in haar $_{\mathrm{i}} /{ }^{*}$ haar $_{\mathrm{j}}$.

Marie gets a strange feeling in her

"Marie is getting a funny feeling"

b. $\mathrm{Jan}_{\mathrm{i}}$ het dit nie in $\mathrm{hom}_{\mathrm{i}} /{ }^{*} \mathrm{hom}_{\mathrm{j}}$ om 'n leier te wees nie. ${ }^{22}$

Jan has it not in him COMP a leader to be NEG

"Jan doesn't have it in him to be a leader"

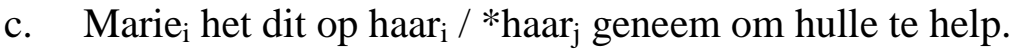

Marie has it on her taken for them to help

"Marie took it upon herself to help them"

b. $\operatorname{Jan}_{\mathrm{i}}$ druk die laken onder $\operatorname{hom}_{\mathrm{i}} / \mathrm{hom}_{\mathrm{j}}$ in.

Jan pushes the sheet under him in

"Jan tucks the sheet in under him"

${ }^{22}$ The item om which co-occurs with the infinitive marker te in infinitival clauses is assumed to be a non-finite complementiser, as in Dutch; cf. e.g. De Villiers (1975: 224-233), Walraven (1975), Ponelis (1979: 247, 429433), Broekhuis et al. (1995), Zwart (1997: 109-116). 
d. $\operatorname{Jan}_{\mathrm{i}}$ sal Marie se woorde altyd met hom $\mathrm{i} / * \mathrm{hom}_{\mathrm{j}}$ saamdra.

Jan will Marie POSS words always with him along-carry

"Jan will always carry Mary's words with him"

In the examples in (23), the pronominal complement of the preposition is also assigned the $\theta$ role of subject-associated location and, as in the case of (22), the pronoun can only be interpreted reflexively. However, in contrast to the pattern in (22), the reflexive must take the complex - self form. ${ }^{23}$

(23) a. Jan glimlag by homself $_{\mathrm{i}} / *$ hom $_{\mathrm{i}} / *$ hom $_{\mathrm{j}}$.

Jan smiles by himself / him

"Jan is smiling by himself"

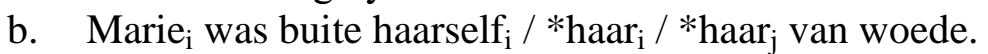

Marie was out herself / her of rage

"Marie was beside herself with rage"

c. $\quad \operatorname{Jan}_{\mathrm{i}}$ is nogal baie in homself $\mathrm{i} / *$ hom $_{\mathrm{i}} / *$ hom $_{\mathrm{j}}$ gekeer.

Jan is rather much in himself / him turned

"Jan is rather wrapped up in thought"

d. Marie $_{\mathrm{i}}$ is uit haarself $\mathrm{i} /$ Haar $_{\mathrm{i}} /{ }^{*}$ haar $_{\mathrm{j}}$ tot niks in staat nie.

Marie is out herself / her to nothing in state NEG

"Marie is not capable of anything of her own will"

One further pattern which seems to involve the location $\theta$-role should be mentioned here. Consider the examples in (24). In each case, the pronominal complement of the preposition is assigned what appears to be a "non-subject-associated location" role. In contrast to the patterns illustrated in (21)-(23), the pronouns in (24) can only be interpreted non-reflexively. ${ }^{24}$

${ }^{23}$ It is not clear how the difference in acceptability patterns between (22) and (23) can be accounted for. One possibility is simply to view the choice of reflexive form (simplex vs. complex) as an intrinsic lexical property of the particular preposition. However, this would mean that a preposition like in would have two incompatible properties, as illustrated in (22a) and (23c). Another possibility is to view utterances like those in (23) as idiomatic expressions, where some parts are lexically invariant (e.g. the preposition and the - self form of the pronoun in (23a)) and other parts can be filled by various items from a restricted set (e.g. the verb slot in (23a), which can be filled by verbs expressing a range of emotions or mental states, such as dink ("think"), wonder ("wonder"), brom ("mutter"), sug ("sigh"), droom ("dream”), vloek ("curse”), gril ("shudder"), etc. For idiomatic constructions, cf. e.g. Hopper and Traugott (1993), Kay and Fillmore (1999) and Wee and Ying (2008).

${ }^{24}$ Notice that the acceptability pattern in (24) is the same as that found with the two subclasses of semantically transitive verbs illustrated in (14) and (15) (cf. also note 16). This pattern is also shown by the examples in (i) below. Here, the pronominal complement of the preposition expresses the thematic relation of accompaniment (cf. Gruber 1965: 55-58), a relation which is associated with an entity accompanying another entity who is performing an activity or experiencing some sort of state. It is not clear, however, whether this relation represents a distinct $\theta$-role of accompaniment or whether it should be subsumed under some other $\theta$-role.

(i) a. $\mathrm{Jan}_{\mathrm{i}}$ het saam met ${ }^{*}$ homself $_{\mathrm{i}} /{ }^{*} \mathrm{hom}_{\mathrm{i}} / \mathrm{hom}_{\mathrm{j}}$ in die koor gesing. Jan has along with himself / him in the choir sang "Jan sang with him in the choir"

b. $\operatorname{Jan}_{\mathrm{i}}$ het die grappie saam met homself $_{\mathrm{i}} /$ hom $_{\mathrm{i}} /$ hom $_{\mathrm{j}}$ geniet. Jan has the joke along with him enjoyed "Jan enjoyed the joke along with him"

c. Marie $\mathrm{i}_{\mathrm{i}}$ was saam met *haarself $\mathrm{i} /$ $^{\mathrm{haar}} \mathrm{h} /$ haar $_{\mathrm{j}}$ op skool.

Marie was together with her at school

"Marie went to school with her"

As illustrated in (i), the preposition typically co-occurs with the item saam ("along", "together (with)") when accompaniment is expressed. Omitting saam often leads to ambiguity - e.g. without saam, (ib) also allows the 
a. $\operatorname{Jan}_{\mathrm{i}}$ stap agter $*$ homself $_{\mathrm{i}} /$ hom $_{\mathrm{i}} /$ hom $_{\mathrm{j}}$.

Jan walks behind himself / him

"Jan is walking behind him"

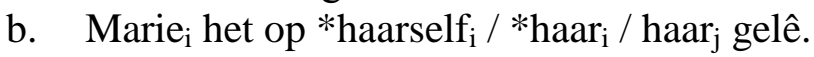

Marie has on herself / her lain

"Marie was lying on her"

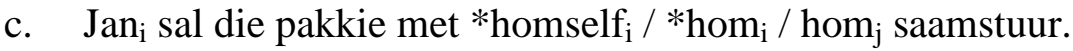

Jan will the parcel with himself / him along-send

"Jan will send a parcel with him"

We turn our attention now to constructions where the PP, comprising a preposition and its object argument, functions as the complement of a noun. Consider the examples in (25). In all these cases, the pronominal complement of the preposition can be interpreted reflexively and non-reflexively, with the simplex form of the pronoun standardly used for the reflexive interpretation. ${ }^{25}$ The pronoun is assigned the location $\theta$-role in (25a), the agent $\theta$-role in $(25 \mathrm{~b})$ and the possessor $\theta$-role in $(25 \mathrm{c})$.

(25) a. $\operatorname{Jan}_{\mathrm{i}}$ ken nie die mense langs hom $\mathrm{i} / \mathrm{hom}_{\mathrm{j}}$ nie.

Jan knows not the people next-to him NEG

"Jan doesn't know the people next to him"

b. Marie ${ }_{i}$ het daardie opmerking deur haar ${ }_{i} /$ haar $_{j}$ bevestig.

Marie has that remark by her confirmed

"Marie confirmed that remark by her"

c. $\mathrm{Jan}_{\mathrm{i}}$ wil 'n verlangse oom van hom / hom $_{\mathrm{j}}$ besoek.

Jan wants-to a distant uncle of him visit

"Jan wants to visit a distantly related uncle of him"

The pattern illustrated in (25) - that is, where the simplex form of the pronoun can have both a reflexive and a non-reflexive interpretation - is also displayed by the examples in (26). Here, the pronoun is assigned the $\theta$-role of theme.

(26) a. Marie ${ }_{i}$ sal die gerugte oor haar ${ }_{i} /$ haar $_{j}$ ontken.

Marie will the rumours about her deny

"Marie will deny the rumours about her"

b. $\mathrm{Jan}_{\mathrm{i}}$ het ' $\mathrm{n}$ foto van $\mathrm{hom}_{\mathrm{i}} / \mathrm{hom}_{\mathrm{j}}$ in die koerant gesien. ${ }^{26}$

Jan has a photo of him in the newspaper seen

"Jan saw a photo of him in the newspaper"

In the examples in (27) and (28), the pronoun also appears to be assigned the theme $\theta$-role. However, in contrast to (26), the simplex form of the pronoun in (27) and (28) cannot be interpreted reflexively; in these cases, reflexivity can only be expressed by the -self form.

interpretation that Jan enjoyed the joke which involved someone else, viz. the entity referred to by the pronoun. In traditional grammars, saam is usually classified as an adverb, and in more recent analyses as a postposition (cf. e.g. Oosthuizen 2000, Biberauer 2008, De Vos 2009).

25 When spoken with primary stress in examples like those in (27), the -self form likely functions to provide emphasis (cf. notes 10 and 20); this also holds for the examples in (28) and the one in (ib) in note 29.

${ }^{26}$ Here, the preposition van is intended to have a representational reading ("he is represented in the photo"), not an agentive reading ("the photo was taken by him") or a possessional reading ("the photo belongs to him"). 
(27) a. $\operatorname{Jan}_{\mathrm{i}}$ het almal behalwe homself $\mathrm{i} / *$ hom $_{\mathrm{i}} /$ hom $_{\mathrm{j}}$ vertrou.

Jan has all except himself / him trusted

"Jan trusted everyone except himself / him"

b. Marie $\mathrm{i}_{\mathrm{i}}$ kan niemand buiten haarself $\mathrm{f}_{\mathrm{i}} /$ haar $_{\mathrm{i}} /$ haar $_{\mathrm{j}}$ blameer nie.

Marie can no-one except herself / her blame NEG

"Marie can blame no-one but herself / her"

(28) a. Marie ${ }_{i}$ het interessante dinge van haarself $f_{i} / *$ haar $_{i} /$ haar $_{j}$ gesê. $^{27}$

Marie has interesting things of herself / her said

"Marie said interesting things about herself / her"

b. $\mathrm{Jan}_{\mathrm{i}}$ sal niks oor homself $_{\mathrm{i}} /$ *hom $_{\mathrm{i}} /$ hom $_{\mathrm{j}}$ verklap nie.

Jan will nothing about himself / him divulge NEG

"Jan won't give away anything about himself / him"

It is not clear how to account for the difference in acceptability patterns between (26) on the one hand, and (27) and (28) on the other hand. Apart from the following observations, this issue will not be examined further in this article. As regards (27), it could perhaps be argued that the pronominal complement of the preposition is actually assigned the $\theta$-role of benefactive (or "malefactive", taking into account the meaning of the sentence). From a thematic point of view, then, the pattern in (27) would be unrelated to the one in (26), which involves the theme role. Alternatively, it could be argued that the sequence [nominal expression $+P P]$ in (27) represents an idiomatic construction (cf. note 23), where (i) the preposition slot is lexically invariant in that it can only be filled by behalwe (or its more formal synonyms buiten, benewens, naas and behoudens, in order of relative obsoleteness), ${ }^{28}$ (ii) the pronominal complement of the preposition must take the -self form if it is used reflexively, and (iii) the nominal slot can only be filled by a quantifier or a quantified expression (e.g. almal ("all"), enigeen ("anyone"), niemand ("no-one"), g'n mens ("no person")). As regards (28), it would seem that sentences of this type involve verbs expressing activities which may be described as "subject-originated", i.e. (deliberate) activities having the subject as originator. ${ }^{29}$

In all the constructions described so far in this section, the reflexive takes as its antecedent the subject of the sentence. Consider, however, the example in (29). In this construction, Piet functions as the indirect object argument of the ditransitive verb wys ("show") and the

\footnotetext{
${ }^{27}$ The prepositions betreffende, insake, omtrent and rakende ("about, concerning"), and their obsolete synonym nopens, can also occur in the construction illustrated in (28), though usually in more formal contexts.

${ }^{28}$ Note that these prepositions all have a quantifier-like "exclusion" function, the only prepositions in Afrikaans with this function.

${ }^{29}$ Some more examples of such verbs are bekend maak ("make known"), kwytraak ("let drop"), meedeel ("say, state"), noem ("mention"), terughou ("keep back"), vertel ("tell") and uitlap ("reveal"). Verbs like agterkom ("realise, discover") and hoor and verneem ("hear, gather, understand") - usually classified as perception verbs - can also be used in the construction illustrated in (28), as shown in (ia). Paradoxically, however, hoor is found in the construction in (28) as well, as shown in (ib), although many native speakers do not have firm intuitions in this case.

(i) a. $\operatorname{Jan}_{\mathrm{i}}$ het iets (interessante dinge) oor homself $\mathrm{i} / * \mathrm{hom}_{\mathrm{i}} /$ hom $_{\mathrm{j}}$ agtergekom (gehoor, verneem). Jan has something (interesting things) about himself / him discovered (heard) "Jan discovered (heard) something (interesting things) about himself / him"

b. $\operatorname{Jan}_{\mathrm{i}}$ het 'n (die) opmerking oor hom ${ }_{\mathrm{i}} /$ hom $_{\mathrm{j}}$ tydens teetyd gehoor (*agtergekom, *verneem). Jan has a (the) remark about him during tea-time heard "Jan heard a (the) remark about him during the tea-break"
} 
expression 'n foto van [pronoun] as the direct object argument; these two arguments are assigned the $\theta$-roles of goal and theme, respectively. The pronominal complement of the preposition van is also assigned a theme $\theta$-role, and standardly takes the morphologically simplex form (although the complex - self form is commonly used as well; cf. notes 10 and 20). The pronoun can be interpreted reflexively (the -self form obligatorily so), taking as its antecedent either the subject or the indirect object. The simplex form can, moreover, also be interpreted non-reflexively, referring on its own to an entity not mentioned in the sentence.

$\operatorname{Jan}_{\mathrm{i}}$ het (vir) Piet ${ }_{\mathrm{j}}$ 'n foto van homself / homself $_{\mathrm{j}} /$ hom $_{\mathrm{i}} /$ hom $_{\mathrm{j}} /$ hom $_{\mathrm{k}}$ gewys. Jan has (for) Piet a photo of himself / him shown "Jan showed Piet a photo of himself / him"

\subsection{Infinitival constructions}

This brings us to constructions where the reflexive forms part of an infinitival clause. Consider the examples in (30), where the infinitival clause is the complement of the verb probeer ("try"). ${ }^{30}$ The pronoun functions as the direct object in (30a) and as the indirect object in (30b). In both cases, the simplex form is interpreted non-reflexively and the complex form reflexively. The -self form (indirectly) enters into a coreferential relationship with the subject of the matrix clause: it takes as its antecedent the PRO subject of the infinitival clause which, in turn, is semantically controlled by the subject of the matrix clause. ${ }^{31}$

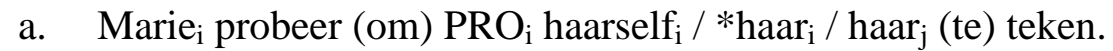
Marie tries (COMP) herself / her (to) draw
"Marie is trying to draw herself / her"
b. $\operatorname{Jan}_{\mathrm{i}}$ probeer (om) $\mathrm{PRO}_{\mathrm{i}}$ homself $_{\mathrm{i}} /$ hom $_{\mathrm{i}} /$ hom $_{\mathrm{j}}$ die kontrak toe(te)ken. Jan tries (COMP) himself / him the contract (to) award "Jan is trying to award himself / him the contract"

As shown in (31), the pattern of acceptability in (30) is also found in sentences where the pronoun occurs in the infinitival complement of the raising verbs blyk and skyn ("appear", "seem"). In this case, the -self form is interpreted coreferentially with the expression which functions as the subject argument of the infinitival clause, but which has been raised to the

\footnotetext{
${ }^{30}$ Probeer is a so-called "conative verb", i.e. a verb which indicates the effort of an entity in performing an activity or getting into some state. One of the grammatical properties of probeer is that it selects a non-finite complement clause which can, but need not, contain the non-finite complementiser om and the infinitive marker te ("to"), with te obligatory if om is present (and not standardly used without om). These facts are illustrated in (i).

(i) a. Jan probeer om PRO die werk te doen.

Jan tries COMP the work to do

"Jan tries to do the work"

b. Jan probeer PRO die werk te doen.

c. *Jan probeer om PRO die werk doen.

d. Jan probeer PRO die werk doen.

Two other conative verbs in Afrikaans are poog (used in more formal contexts) and its obsolete synonym trag; the idiomatic expression 'n poging aanwend ("make an attempt") is also used to express conativity. Unlike probeer, these items do not select an infinitival complement of the type in (id).

${ }^{31}$ Cf. e.g. Carnie (2002) and Radford (2009) for accessible discussions of PRO, control structures and control theory. As far as could be ascertained, no generative studies have yet been done on control structures in Afrikaans; some proposals on the interpretation of PRO are presented in Oosthuizen (2013a).
} 
structural subject position of the matrix clause.

$\mathrm{Jan}_{\mathrm{i}}$ skyn homself $_{\mathrm{i}} / * \mathrm{hom}_{\mathrm{i}} /$ hom $_{\mathrm{j}}$ te haat.

Jan seems himself / him to hate

"Jan seems to hate himself / him"

If the infinitival clause contains an inherently reflexive verb, however, the pronoun can only be interpreted reflexively and is standardly used without -self, as illustrated in (32).

a. $\operatorname{Jan}_{\mathrm{i}}$ probeer (om) $\mathrm{PRO}_{\mathrm{i}}$ hom $_{\mathrm{i}} / * \mathrm{hom}_{\mathrm{j}}(\mathrm{te})$ verset teen die aanval.

Jan tries (COMP) him (to) resist against the attack

"Jan is trying to resist the attack against him"

b. Marie skyn haar $_{i} / *$ haar $_{\mathrm{j}}$ goed te gedra.

Marie seems her well to behave

"Marie seems to behave herself well"

Consider next the examples in (33) and (34). ${ }^{32}$ The pronoun functions as the direct object in (33) and as the indirect object in (34). The simplex form can be interpreted non-reflexively as well as reflexively in both constructions; in the latter case, the pronoun can be coreferential with any one of the arguments in the matrix clause. The -self form is also commonly used to express reflexivity in these constructions. In such cases, however, the pronoun takes as its antecedent the PRO subject of the infinitival clause which, depending on the properties of the matrix verb, can be semantically controlled by the subject of the matrix clause (as in the (a) sentences) or by a non-subject expression (as in the (b) sentences).

(33) a. Jan belowe vir Piet $_{j}$ om PRO $_{\mathrm{i}}$ homself $_{\mathrm{i}} /$ *homself $_{\mathrm{j}} /$ hom $_{\mathrm{i}} /$ hom $_{\mathrm{j}} /$ hom $_{\mathrm{k}}$ te skeer.

Jan promises for Piet COMP himself / him to shave

"Jan promises Piet to shave himself / him"

b. $\operatorname{Jan}_{\mathrm{i}}$ vra vir Piet om $\mathrm{PRO}_{\mathrm{j}}$ *homself $\mathrm{i} /$ homself $_{\mathrm{j}} /$ hom $_{\mathrm{i}} /$ hom $_{\mathrm{j}} /$ hom $_{\mathrm{k}}$ te skeer.

Jan asks for Piet COMP himself / him to shave

"Jan asks Piet to shave himself / him"

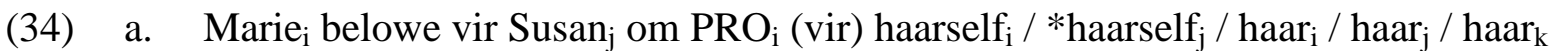

Marie promises for Susan COMP (for) herself $/$ her

'n rok te koop.

a dress to buy

"Marie promises Susan to buy herself / her a dress"

b. Marie vra vir Susan $_{\mathrm{j}}$ om $\mathrm{PRO}_{\mathrm{j}}$ (vir) *haarself $/$ haarself $_{\mathrm{j}} /$ haar $_{\mathrm{i}} /$ haar $_{\mathrm{j}} /$ haar $_{\mathrm{k}}$

Marie asks for Susan COMP (for) herself / her

'n rok te koop.

a dress to buy

"Marie asks Susan to buy herself / her a dress"

\footnotetext{
${ }^{32}$ The matrix verbs in (33) and (34) both concern a future activity of an entity: belowe ("promise") in the (a) sentences indicates a commitment by the agent to perform such an activity, whereas vra ("ask") in the (b) sentences indicates an attempt by the agent to somehow influence (manipulate, direct, control, etc.) a future activity of some other entity.
} 
On the face of it, the pronoun can also function as the subject of an infinitival clause, as in (35) and (36). ${ }^{33}$ In such cases, the - self form is interpreted reflexively and the simplex form non-reflexively.

(35) a. Jan laat homself $_{\mathrm{i}} /{ }^{*} \mathrm{hom}_{\mathrm{i}} / \mathrm{hom}_{\mathrm{j}}$ die ondersoek lei.

Jan lets himself / him the investigation lead

"Jan puts himself / him in charge of the investigation"

b. Marie maak haarself $_{\mathrm{i}} /$ *haar $_{\mathrm{i}} /$ haar $_{\mathrm{j}}$ die medisyne drink.

Marie makes herself / her the medicine drink

"Marie forces herself / her to drink the medicine"

a. $\quad \operatorname{Jan}_{\mathrm{i}}$ hoor homself $\mathrm{i} / * \mathrm{hom}_{\mathrm{i}} /$ hom $_{\mathrm{j}}$ lag.

Jan hears himself / him laugh

"Jan hears himself / him laugh"

b. Marie sien haarself $_{\mathrm{i}} /$ *haar $_{\mathrm{i}} /$ haar $_{\mathrm{j}}$ op die strand lê.

Marie sees herself / her on the beach lie

"Marie sees herself / her lying on the beach"

In (35), the matrix verbs laat ("let") and maak ("make") indicate the nature of the agent's involvement in some activity or state, where (i) this involvement ranges over intentional acts or conscious attitudes of coercion, permission, acceptance and effectuation, and (ii) the relevant activity or state can be entered into by either the agent or some other entity. ${ }^{34}$ In (36), the infinitival clause forms the complement of the "passive" perception verbs hoor ("hear") and sien ("see"), which denote the experience or state of using a particular sense (as opposed to "active" perception verbs like luister ("listen") and kyk ("look") which denote the activity of using the relevant sense). ${ }^{35}$ Both types of matrix verb in (35) and (36) select a bare

${ }^{33}$ It is argued in Oosthuizen (2013a: section 3.2.4.2) that the pronoun in sentences like (35) and (36) actually represents the object argument of the matrix verb (in the sense that it receives its $\theta$-role from this verb); at the same time though, it is semantically associated with the PRO subject of the infinitival clause.

${ }^{34}$ An interesting property of laat, one not shared by maak, is that it can select a passive infinitival complement. This is illustrated by the examples in (i), where the pronoun functioning as the direct object argument occurs in the derived subject position. Note that the infinitival clause can optionally contain a deur ("by")-phrase and, less commonly, the passive auxiliary word ("be"). In such cases, the reflexive standardly takes the simplex form, which can be interpreted non-reflexively as well. (The -self form of the reflexive is also commonly used, possibly under the influence of English or to add emphasis; cf. notes 6 and 10.)

(i) a. $\operatorname{Jan}_{\mathrm{i}}$ laat hom $_{\mathrm{i}} / \mathrm{hom}_{\mathrm{j}}$ oortuig (word) (deur Piet).

Jan lets him persuaded (be) (by Piet)

Jan is letting himself / him be persuaded (by Piet)"

b. Marie laat haar $_{\mathrm{i}} /$ haar $_{\mathrm{j}}$ nomineer (word) (deur Susan).

Marie lets her nominated (be) (by Susan)

"Marie is letting herself / her be nominated (by Susan)"

${ }^{35}$ As illustrated in (i), the pattern of acceptability in (36) is also found in sentences where the infinitival clause functions as the complement of an "active" perception verb. It should be noted, though, that many native speakers do not have firm acceptability judgements about examples like these, the interpretation of which seems to be very dependent on the context.

(i) a. $\operatorname{Jan}_{\mathrm{i}}$ luister na homself $\mathrm{i} / * \mathrm{hom}_{\mathrm{i}} / \mathrm{hom}_{\mathrm{j}}$ beloftes maak.

Jan listens to himself / him promises make

"Jan listens to himself / him making promises"

b. Marie kyk na haarself $_{\mathrm{i}} / *$ haar $_{\mathrm{i}} /$ haar $_{\mathrm{j}}$ oefeninge doen.

Marie looks at herself / her exercises do

"Marie looks at herself / her doing exercises" 
infinitival complement, that is, a non-finite clause which lacks the overt complementiser om and infinitive marker te. Also, with both verb types, the pronoun can function as the direct object or the indirect object of the infinitival complement, as shown in (37) and (38), respectively; in these examples, the pattern of acceptability is the same as that illustrated in (33b) and (34b).

a. $\operatorname{Jan}_{\mathrm{i}}$ laat Piet $_{\mathrm{j}}$ *homself $\mathrm{i} /$ homself $_{\mathrm{j}} /$ hom $_{\mathrm{i}} /$ hom $_{\mathrm{j}} /$ hom $_{\mathrm{k}}$ inspuit.

Jan lets Piet himself / him inject

"Jan lets Piet inject himself / him"

b. Marie hoor Susan $_{j}$ *haarself $_{\mathrm{i}} /$ haarself $_{\mathrm{j}} /$ haar $_{\mathrm{i}} /$ haar $_{\mathrm{j}} /$ haar $_{\mathrm{k}}$ verdedig. $^{\text {. }}$

Marie hears Susan herself / her defend

"Marie hears Susan defending herself / her"

(38) a. $\operatorname{Jan}_{\mathrm{i}}$ maak Piet $_{\mathrm{j}}$ (vir) *homself $/$ homself $_{\mathrm{j}} /$ hom $_{\mathrm{i}} /$ hom $_{\mathrm{j}} /$ hom $_{\mathrm{k}}$ 'n gereg voorberei.

Jan makes Piet (for) himself / him a meal prepare

"Jan made Piet prepare himself / him a meal"

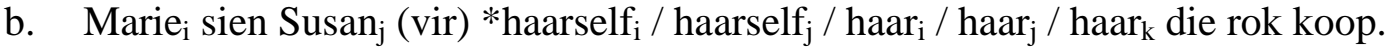

Marie sees Susan (for) herself / her the dress buy

"Marie sees Susan buying herself / her the dress"

\subsection{Small clause constructions}

We now turn to sentences where the reflexive forms part of a small clause (SC). ${ }^{36}$ Consider the examples in (39). Here, the SCs all function as the complement of a resultative verb, that is, a verb denoting an activity which affects the SC subject, the result of which is described by the (often hyperbolic) SC predicate. ${ }^{37}$ In each case, the pronominal subject of the SC can be interpreted both reflexively and non-reflexively. On its reflexive interpretation, the pronoun standardly takes the morphologically simplex form, although the -self form is also commonly used. $^{38}$ The non-verbal predicates are the AP bankrot ("bankrupt") in (39a), the PP in 'n depressie in ("into a depression") in (39b) and the DP 'n wrak ("a wreck") in (39c).

a. $\quad \operatorname{Jan}_{\mathrm{i}} \mathrm{koop} \mathrm{hom}_{\mathrm{i}} / \mathrm{hom}_{\mathrm{j}}$ bankrot.

Jan buys him bankrupt

"Jan is shopping away all his money"

\footnotetext{
${ }^{36}$ The expression "small clause" is used in the literature to refer to a variety of constructions which (i) typically contain a subject argument and a non-verbal predicate, and (ii) are "smaller" than finite and infinitival clauses in the sense that "they do not contain complementizers, auxiliary verbs, tense markers, or elements similar to the [English] particle to preceding the verb in an infinitive" (Fromkin 2000: 133). Several proposals have been made about the internal structure of different types of SCs, and the general assumption seems to be that each type is a projection of some or other functional category; cf. e.g. Williams (1983), Hoekstra (1988), Bowers (1997), Adger and Ramchand (2003), Den Dikken (2006) and Citko (2008). For an analysis of SCs in Afrikaans, cf. Backhouse (2014).

37 For resultative verbs and structures, cf. e.g. Williams (1980), Levin (1993), Wechsler (1997), Rappaport Hovav and Levin (2001), Goldberg and Jackendoff (2004), Williams (2008), and the references in note 36. The schematic form [subject verb [subject XP]] of the utterances in (39) is productively used in the formation of (at least partially) idiomatic expressions in Afrikaans, where (i) the two subject slots are open (although the SC subject must be a reflexive in some cases; cf. the examples in (42) and (43)), and (ii) the verb and XP slots are restricted in some or other way (with a possible selection relationship between the verb and the XP); cf. also note 23 and the discussion of (26)-(28) above.

${ }^{38}$ These remarks hold for the examples in (40)-(43) as well; cf. notes 6 and 10.
} 
b. Marie praat haar $_{\mathrm{i}} /$ haar $_{\mathrm{j}}$ in 'n depressie in.

Marie talks her in a depression in

"Marie is talking herself / her into a depression"

c. $\operatorname{Jan}_{\mathrm{i}}$ het hom $\mathrm{i} /$ hom $_{\mathrm{j}}$ 'n wrak gedrink.

Jan has him a wreck drunk

"Jan drank himself / him to dereliction"

The pattern of acceptability in (39) is also found in constructions containing what may be called "mental appraisal" and "institutional performative" verbs, as illustrated in (40) and (41), respectively. ${ }^{39}$

(40) a. $\operatorname{Jan}_{\mathrm{i}}$ ag hom $\mathrm{i} /$ hom $_{\mathrm{j}}$ die beste kandidaat.

Jan deems him the best candidate

"Jan deems himself / him the best candidate"

b. Marie vind haar $_{\mathrm{i}} /$ haar $_{\mathrm{j}}$ bekwaam genoeg.

Marie finds her competent enough

"Marie finds herself / her competent enough"

(41) a. $\operatorname{Jan}_{\mathrm{i}}$ noem hom $_{\mathrm{i}} / \mathrm{hom}_{\mathrm{j}}$ die leier van die beweging.

Jan names him the leader of the movement

"Jan calls himself / him the leader of the movement"

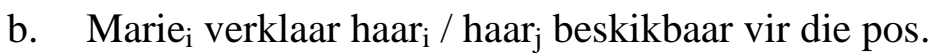

Marie declares her available for the post

"Marie declares herself / her available for the position"

There are, however, at least two types of construction where the pronominal subject of the SC is obligatorily interpreted as a reflexive. In the first type, the SC functions as the complement of an inherently reflexive verb, as in (42).

(42) a. $\operatorname{Jan}_{\mathrm{i}}$ het homi $/ * \mathrm{hom}_{\mathrm{j}}$ stokflou teengesit.

Jan has him dead-tired resist

"Jan resisted to the point of exhaustion"

b. Marie skaam haar $_{\mathrm{i}} /$ *haar $_{\mathrm{j}}$ bloedrooi. $^{\text {s }}$

Marie shames her blood-red

"Marie is turning crimson with shame"

c. $\operatorname{Jan}_{\mathrm{i}}$ het hom $\mathrm{i} / * \mathrm{hom}_{\mathrm{j}}$ heeltemal deur die wind verslaap.

Jan has him completely through the wind overslept

"Jan was in a state of confusion after oversleeping himself"

The second type, by contrast, does not lend itself to a characterisation in terms of the properties of the matrix verb alone. Rather, in this case, the semantic properties of the SC predicate seem to be crucial in determining whether the construction is obligatorily reflexive or not. Consider the examples in (43). ${ }^{40}$

\footnotetext{
${ }^{39}$ Many native speakers seem to find utterances like those in (40) and (41) less acceptable when the simplex form of the pronoun is used with a reflexive interpretation, preferring the -self form in such cases.

40 The verbs in (43) are all syntactically intransitive (although those in (a,b) can be used transitively in other contexts), and, unlike inherently reflexive verbs, they cannot take a reflexive on its own as an object complement (cf. *Jan het hom $_{i}{\text { geskree, }{ }^{*} \text { Marie }_{i} \text { drink haar }}_{i}$, etc.).
} 
(43) a. $\operatorname{Jan}_{\mathrm{i}}$ het hom $\mathrm{i} / * \mathrm{hom}_{\mathrm{j}}$ hees geskree.

Jan has him hoarse shouted

"Jan shouted himself hoarse"

b. Marie drink haar $_{\mathrm{i}} /$ *haar $_{\mathrm{j}}$ in 'n koma in.

Marie drinks her in a coma in

"Marie is drinking herself into a coma"

c. $\operatorname{Jan}_{\mathrm{i}} \mathrm{staar}_{\mathrm{hom}} /$ $^{*} \mathrm{hom}_{\mathrm{j}}$ blind teen die hoë misdaadsyfer.

Jan stares him blind against the high crime-rate

"Jan is blind to everything but the high crime rate"

d. $\quad$ Marie $_{\mathrm{i}}$ skrik haar $\mathrm{i} / *$ haar $_{\mathrm{j}}$ lam.

Marie startle her paralysed

"Marie is paralysed with fright"

It is not clear which properties of the SC predicate (presumably in conjunction with the properties of the matrix verb) are involved in bringing about the obligatorily reflexive nature of the construction illustrated in (43). On the face of it, the pronoun in the schema [subject verb [pronoun $X P$ ]] receives an obligatorily reflexive interpretation if (i) the matrix verb describes an internally-caused activity or event, ${ }^{41}$ and (ii) the predicate XP describes an inalienable or non-transferable attribute which results from this activity or event (e.g. becoming hoarse, paralysed, blind, etc.). Whether these observations represent a valid generalisation remains a topic for further investigation.

\section{Possessives and possessive constructions}

Afrikaans possessive pronouns are traditionally divided into two subclasses (cf. Ponelis 1979: 83-84). Those of the first subclass, listed in (44) below, can occur in a postnominal predicate position (i.e. after the possessee, as in Die boek is myne ("The book is mine")), and can also be used independently (i.e. without some other expression representing the possessee, as in Myne is gesteel ("Mine was stolen")).

$\begin{array}{ll}1^{\text {st }} \mathrm{SG}: & \text { myne ("mine”) } \\ 1^{\text {st }} \mathrm{PL}: & \text { ons s'n ("ours") } \\ 2^{\text {nd }} \mathrm{SG}: & \text { joune (“yours"); u s'n (formal) } \\ 2^{\text {nd }} \mathrm{PL}: & \text { julle s'n ("yours"), u s'n (formal) } \\ 3^{\text {rd }} \mathrm{SG}: & \text { syne (M/N, "his"/“its"); hare (F, "hers") } \\ 3^{\text {rd }} \mathrm{PL}: & \text { hulle s'n ("theirs") }\end{array}$

As shown in (44), plural possessive pronouns of this subclass obligatorily occur with the item $s$ 'n (historically related to "his"), which most likely also represents some sort of possessive element but which cannot be used on its own. As illustrated in (45), $s$ ' $n$ is standardly used in

\footnotetext{
41 Rappaport Hovav and Levin (2001: 790-791) draw the following distinction between verbs denoting externally caused activities or events and those denoting internally caused activities or events: "Externally caused verbs describe eventualities conceptualized as being brought about by an external cause with immediate control over the eventuality. Core members of this class are verbs of change of state (break, close, thicken). [...] In contrast, internally caused verbs describe eventualities that are conceptualized as arising from inherent properties of the verb's argument. These properties are 'responsible' for the eventuality denoted by an internally caused verb. Such verbs include laugh, play, speak, walk, buzz, and glow, as well as a few verbs of change of state, such as bloom, rot, and deteriorate." Cf. also McKoon and Macfarland (2000).
} 
possessive constructions with full nominal expressions, proper nouns, interrogative pronouns and relative pronouns.

(45) a. Die boek is die meisie s'n / Marie s'n.

the book is the girl his / Marie his

"It is the girl's book / Marie's book"

b. Wie s'n is dit? / Ek ken 'n meisie wie s'n gesteel is. who his is it / I know a girl who his stolen was "Whose is it? / I know a girl whose was stolen"

In sentences where a possessive pronoun of the subclass in (44) is used independently, it can be interpreted both reflexively and non-reflexively, as illustrated in (46); used as a reflexive, the pronoun in this example can take as its antecedent either the subject or the indirect object.

(46) Talking about presents:

$\mathrm{Jan}_{\mathrm{i}}$ het vir Piet syne $_{\mathrm{i}} /$ syne $_{\mathrm{j}} / \mathrm{syne}_{\mathrm{k}}$ gegee.

Jan has for Piet his given

"Jan gave Piet his"

The discussion in the rest of this section will focus on possessive pronouns of the second subclass. These pronouns are used attributively and occur in a prenominal position (i.e. before the possessee, as in my boek ("my book")). The members of this subclass are given in the following table:

Table 2: (Prenominal) possessive pronouns in Afrikaans

\begin{tabular}{|c|c|c|c|c|}
\hline Person & Number & Gender & Pronoun & Formal \\
\hline 1 & SG & - & my & - \\
\hline 1 & PL & - & ons & - \\
\hline 2 & SG & - & jou & u \\
\hline 2 & PL & - & julle/jul & u \\
\hline 3 & SG & M/N & sy & - \\
\hline 3 & SG & F & haar & - \\
\hline 3 & PL & M/F/N & hulle/hul & - \\
\hline
\end{tabular}

With one exception, Afrikaans possessive pronouns standardly do not have morphophonologically distinct genitive case forms and are indistinguishable from personal pronouns displaying accusative case, as shown in Table 2. The exception is the third-person singular masculine/neuter pronoun which takes the genitive case form sy ("his"). In some non-standard varieties of Afrikaans, notably those spoken in the north-western parts of South Africa, the pronoun used in possessive constructions commonly occurs together with the 
particle se, most likely some sort of possessive marker (POSS), as in my se ma ("my mother") and hulle se kinders ("their children"). ${ }^{42}$ In the non-standard varieties at hand, the third-person singular masculine/neuter pronoun usually takes the form hom, and also occurs with se (although, less commonly, se can be omitted), as in hom (se) huis ("his house"). ${ }^{43}$

As illustrated by the examples in (47), the prenominal possessive pronouns in Table 2 can be used reflexively. In (47a), the nominal expression containing the possessive pronoun functions as the direct object argument, in (47b) as the indirect object argument, and in (47c,d) as the complement of a preposition. In all these examples, the pronoun can be interpreted reflexively as well as non-reflexively; however, unlike the traditional category of reflexive pronouns, these possessive pronouns cannot take the morphologically complex -self form.

a. $\quad \operatorname{Jan}_{\mathrm{i}}$ verf $*^{*}$ syself $_{\mathrm{i}}$ huis / $\mathrm{sy}_{\mathrm{i}}$ huis / $\mathrm{sy}_{\mathrm{j}}$ huis.

Jan paints his house

"Jan is painting his house"

b. Marie i $_{\mathrm{i}}$ het (vir) *haarself $\mathrm{i}_{\mathrm{i}}$ ma / haar $\mathrm{h}_{\mathrm{i}}$ ma / haar $\mathrm{j}_{\mathrm{j}}$ ma 'n geskenk gegee.

Marie has (for) her mother a present given

"Marie gave her mother a present"

c. $\quad \mathrm{Jan}_{\mathrm{i}}$ speel met $^{*} \mathrm{syself}_{\mathrm{i}}$ kinders / $\mathrm{sy}_{\mathrm{i}}$ kinders / $\mathrm{sy}$ kinders.

Jan plays with his children

"Jan is playing with his children"

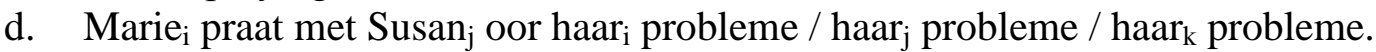

Marie talks to Susan over her problems

"Marie is talking to Susan about her problems"

Incidentally, it was pointed out in section 2 that, in some styles, vocative items which are integrated into sentence structure are used in place of elements belonging to the traditional lexical category of reflexive pronouns. Similarly, such integrated vocative items can occur in place of possessive pronouns which are used reflexively. In such cases, the vocative item shows exactly the same characteristics regarding co-occurrence with the particles se and $s$ 'n as full nominal expressions and proper nouns which are used in possessive constructions (cf. above and note 43). These facts are illustrated in (48).

a. Mamma het Mamma se hare gewas.

Mommy has Mommy POSS hair washed

"Mommy has to wash Mommy's/her hair"

\footnotetext{
${ }^{42}$ This use of a possessive pronoun together with se is also found in the conventionalised opening words of The Lord's Prayer, Onse Vader ("Our Father").

${ }^{43}$ The use of $s e$ is the standard way of expressing a possessor relation in possessive constructions involving full nominal expressions (die meisie se ma ("the girl's mother")), proper nouns (Jan se huis ("Jan's house")), interrogative pronouns (Wie se kind is jy? ("Whose child are you?")) and relative pronouns (die mense wie se huis verkoop is ("the people whose house was sold")). Cf. Den Besten (1978: 28-38) and Oosthuizen and Waher (1994) for descriptions of Afrikaans possessive constructions within a generative framework, and Ponelis (1979) and Van Schoor (1983) for non-generative descriptions. Cf. also Barbiers and Bennis (s.a.), Corver (2003) and Corver and Van Koppen (2010) for analyses of related facts in several Dutch dialects, and Ponelis (1979: 126-129) and Quirk et al. (1985: 321-322) for the various types of meaning that can be expressed by possessive pronouns in Afrikaans and English, respectively.
} 


\section{b. Talking about cars:}

Dokter moet Dokter s'n verkoop!

doctor must doctor his sell

"You should sell yours, Doctor!"

As a rule, the possessive pronoun is interpreted reflexively when it occurs in a whole-part genitive construction, as shown in (49). In these examples, the pronoun is used to express a possessor relation involving a person and a body part (or a person and an internally caused activity or event; see note 41$){ }^{44}$

a. Marie spits haar $_{\mathrm{i}}$ ore / *haar ore.

Marie pricks-up her ears

"Marie pricks up her ears"

b. $\quad \operatorname{Jan}_{\mathrm{i}} \mathrm{kon} \mathrm{sy}_{\mathrm{i}}$ lag / ${ }^{*} \mathrm{sy}_{\mathrm{j}}$ lag nie hou nie.

Jan could his laugh not keep NEG

"Jan couldn't stop himself from laughing"

c. Marie i $_{\mathrm{i}}$ het die nuus in haar ${ }_{\mathrm{i}}$ hart / *haar ${ }_{\mathrm{j}}$ hart bewaar.

Marie has the news in her heart preserved

"Marie kept the news close to her heart"

d. $\quad \operatorname{Jan}_{\mathrm{i}}$ het dit met sy $\mathrm{y}_{\mathrm{i}}$ eie oë / *syj eie oë gesien.

Jan has it with his own eyes seen

"Jan saw it with his own eyes"

The item eie ("own") is often used together with possessive pronouns, as in (49d), and also with the possessive marker se (cf. note 43). It is not clear to which category eie belongs and what its exact functions are. One possibility, worked out by Barbiers and Bennis (s.a.: 2-3) for the analogous item eigen in some Dutch dialects, is to analyse it as a non-pronominal possessive marker - presumably a functional head - which takes a possessive pronoun as its specifier. Another possibility is to analyse it as an adjective which is used to indicate, among other things, a biological relationship (my eie kinders, nie my stiefkinders nie ("my own children, not my stepchildren")), freedom from control (sy eie kop volg ("follow his own head")), and exclusivity (vir julle eie gebruik ("for your own use")). It should be noted in this regard that the form eie can also be used pronominally, as in My eie (kinders) is al getroud ("My own (children) are already married") and Sy doen dit uit haar eie (oortuiging) uit ("She's doing it out of her own (conviction)"). A third possibility, assumed by Ponelis (1979: 127), is that eie is used to provide emphasis, specifically to strengthen or intensify the possessive pronoun (and also, presumably, the possessor expression occurring with the possessive marker se). In this regard then, Ponelis views eie as functionally similar to the suffix -self; cf. notes 6 and 10. A fourth, related possibility could be that eie represents a

\footnotetext{
${ }^{44}$ Sentences of the types illustrated in (49) - and also in (50) - often contain constructions that are (partially) idiomatic or conventionalised, specifically where a particular verb (or verbs from a restricted set) selects a nominal complement with an open possessive pronoun slot and a lexically invariant noun (i.e. possessee) slot, as in (ia) below; in cases where the nominal expression forms part of a PP, the preposition slot is also often restricted to a particular preposition, as in (ib). Cf. Ponelis (1979: 229-230) for further examples, and also notes 23 and 37.

(i) a. julle ore spits ("prick up your ears"); sy laaste asem uitblaas ("give his last breath"); haar bewussyn verloor/herwin ("lose/gain (her) consciousness")

b. agter hulle rug beledig/slegsê ("insult behind their backs"); uit sy maag uit lag ("laugh from his belly") na haar asem snak ("gasp for (her) breath")
} 
contrastive focus marker (or conceivably a possessor focus marker), typically spoken with primary stress, as in my EIE huis, nie iemand anders s'n nie ("my OWN house, not someone else's"). This possibility could perhaps explain the unacceptability of the examples in (50), where the possessee does not lend itself to a contrastive interpretation. However, it could also be argued that the italicised sequences in (50) are fixed idiomatic expressions with no slot for eie, whereas such an eie slot is required in, for example, (49d).

(50) a. *Jan het uit sy eie maag uit gelag.

Jan has out his own belly out laughed

b. *Marie het die nuus in haar eie hart bewaar.

Marie has the news in her own heart preserved

c. *Jan het die huis in sy eie gedagtes gesien. Jan has the house in his own thoughts seen

d. *Marie het vir Susan agter haar eie rug beledig. Marie has for Susan behind her own back insulted

The four possibilities referred to above will not be examined further here. There are, however, two further observations that may be worth mentioning. First, when used in a prenominal position, i.e. before the possessee, eie cannot be split from the possessive pronoun or the possessive marker se; in other words, the sequence [possessive pronoun / se $+e i e$ ] forms an inseparable unit. Second, as was pointed out above, possessive pronouns display distinctive forms when they are used in a postnominal predicate position or in sentences without an expression representing the possessee: SG pronouns take the ending -ne (myne, joune, syne) and PL pronouns combine with the element $s^{\prime} n$ (ons s'n, julle s'n, hulle s'n). The item $s^{\prime} n$ is likewise used with full nominal expressions, proper nouns, interrogative pronouns and relative pronouns in these constructions. However, as illustrated in (51), when eie is used in the possessive constructions at hand, the possessive pronouns occur without $-n e$ and $s$ ' $n$, and all the other possessive expressions have $s e$ in place of $s$ 'n.

(51) a. Die huis is sy eie / *syne eie.

b. Ons eie / *ons s'n eie is ook gesteel.

c. Die boek is die meisie se eie / *die meisie s'n eie.

d. 'Wie se eie / *wie s'n eie is te koop?

Consider next the examples in (52). The verbs in these sentences denote various types of action directed at a non-agent entity, including actions which entail a range of intentions or mental states on the part of the agent (spitefulness, maliciousness, kindness, compassion, anxiety, etc.), physical contact (often by impact and directed at a specific body part), and/or sudden movement. As in (49), the pronouns in (52) can only be interpreted reflexively; in these cases, however, the pronoun cannot take the subject as its antecedent.

(52) a. Marie ${\text { gryp vir } \operatorname{Susan}_{j} \text { aan *haar }}_{\mathrm{i}}{\operatorname{arm} / \text { haar }_{\mathrm{j}} \operatorname{arm}_{\text {arm }} \text { *haar }}_{\mathrm{k}} \operatorname{arm}_{\text {arm }}$

Marie grabs for Susan on her arm

"Marie grabs Susan by the arm" 
b. $\quad \operatorname{Jan}_{\mathrm{i}}$ het die man in $*_{\mathrm{s}} \mathrm{y}_{\mathrm{i}}$ voet $/ \mathrm{sy}_{\mathrm{j}}$ voet / $*_{\mathrm{s}} \mathrm{y}_{\mathrm{k}}$ voet geskiet. ${ }^{45}$

Jan has the man in his foot shot

"Jan shot the man in his foot"

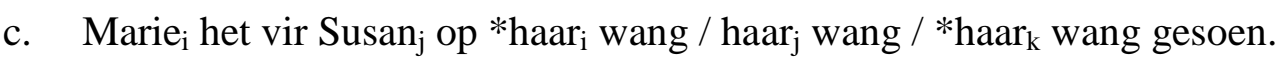

Marie has for Susan on her cheek kissed

Marie kissed Susan on her cheek"

d. $\quad \operatorname{Jan}_{\mathrm{i}}$ slaan vir Piet $\mathrm{j}_{\mathrm{j}}$ op ${ }^{*} \mathrm{sy}_{\mathrm{i}}$ neus / $\mathrm{sy}_{\mathrm{j}}$ neus / ${ }^{*} \mathrm{sy}_{\mathrm{k}}$ neus.

Jan hits for Piet on his nose

"Jan hits Piet on the nose"

Unlike in (51) and (52), the pronouns in the examples in (53) can only be interpreted nonreflexively. In each case, the event which is described concerns a non-agent entity who is either not directly or only passively involved in the particular action.
a. $\quad$ Marie $_{\mathrm{i}}$ versprei stories agter *haar $_{\mathrm{i}}$ rug / haar ${ }_{\mathrm{j}}$ rug.
Marie spreads stories behind her back
"Marie is spreading stories behind her back"
b. $\quad \operatorname{Jan}_{\mathrm{i}}$ neem die besluit sonder $*^{*} \mathrm{~s}_{\mathrm{i}}$ goedkeuring / sy $\mathrm{j}_{\mathrm{j}}$ goedkeuring.
Jan takes the decision without
his approval
"Jan takes the decision without his approval"
c. Marie het voor *haar $_{\mathrm{i}}$ oë / haar j $_{\mathrm{j}}$ ö flou geval.
Marie has before her eyes faint fallen
"Marie fainted right before her eyes"

\section{Summary}

The objective of this article was to provide a non-formalistic description of the traditional class of reflexive pronouns in Afrikaans and of the diverse constructions in which they can occur.

Afrikaans reflexives come in two forms, namely morphologically simplex forms which are indistinguishable from personal pronouns in the accusative case form, and morphologically complex forms where the pronoun takes the suffix -self. The simplex form is standardly used in two contexts: when the pronoun occurs (i) as the syntactic complement of an inherently reflexive verb, and (ii) as the complement of an inherently reflexive preposition (where such verbs and prepositions are shown to belong to various semantic classes). The pronoun is interpreted as obligatorily reflexive in both these contexts, even though it has the same form as the corresponding personal pronoun displaying accusative case. However, in colloquial speech it is also common for the reflexive to take the -self form in the two contexts just mentioned. In such cases, the utterance can be spoken with the primary stress on the suffix - self, in contrast to the normal, non-emphatic sentence stress pattern where the verb receives the primary stress.

\footnotetext{
${ }^{45}$ Where a sentence like (52b) contains a pronominal direct object argument, as in (i) below, the possessive pronoun is still interpreted coreferentially with the direct object. Note, however, that the direct object can be interpreted in two ways in this case: (a) reflexively, taking the subject as its antecedent, and (b) nonreflexively, independently referring to some other entity. If (a), the possessive pronoun is coreferential with the subject, and if (b), coreferential with the non-reflexive direct object.

(i) a. $\operatorname{Jan}_{\mathrm{i}}$ het hom $\mathrm{i}$ in $\mathrm{sy}_{\mathrm{i}}$ voet / ${ }^{\mathrm{s}} \mathrm{y}_{\mathrm{j}}$ voet geskiet.

b. $\operatorname{Jan}_{i}$ het hom ${ }_{j}$ in ${ }^{*} s_{i}$ voet $/ s_{j}$ voet geskiet.
} 
Aside from being used with inherently reflexive verbs and prepositions in colloquial speech, the morphologically complex form of the reflexive is standardly found with verbs and prepositions which are not inherently reflexive, but which are compatible with a reflexive reading. In the majority of such cases, the reflexive reading can only be expressed through the use of the suffix -self; that is to say, the pronoun cannot be interpreted reflexively without -self. However, there are some semantic classes of verbs and prepositions which, although not inherently reflexive, do allow a reflexive reading for the simplex form of the pronoun. Even so, in these cases too, an obligatory reflexive reading is only possible with the complex -self form; the simplex form, by contrast, is ambiguous between the two readings. The semantic classes in question include verbs which describe typically self-directed actions (section 3.1), resultative and mental appraisal verbs (3.4), and prepositions which assign $\theta$-roles such as agent, possessor and (physical or abstract) location (3.2).

In addition to the traditional class of reflexive pronouns, possessive pronouns can also be used reflexively; these pronouns do not occur with the suffix -self. The possessive pronoun generally allows both a reflexive and a non-reflexive interpretation. However, in section 4, two constructions were identified in which the possessive pronoun receives an obligatory reflexive interpretation. The first is where the pronoun occurs in a whole-part construction, for example, where it is used to express a possessor relation involving a person and a body part (or a person and an internally caused activity/event). The second obligatory reflexive construction containing a possessive pronoun is where the verb denotes various types of action directed at a non-agent entity, including actions which entail a range of intentions or mental states on the part of the agent.

The above facts were illustrated with reference to various types of construction in which reflexives can occur: verbal object and double object constructions (section 3.1), prepositional object constructions (3.2), raising and control constructions (3.3), small clause constructions (3.4), and possessive constructions (section 4). In the course of discussing these constructions, it was shown that, besides the subject, the reflexive can also take as its antecedent an expression functioning as the direct object, the indirect object or as a prepositional object. Furthermore, it was shown that Afrikaans has a number of non-reflexive constructions as well, that is, constructions containing inherently non-reflexive verbs and prepositions which rule out a coreferential relationship between the pronoun and some other expression in the sentence.

The findings of this article represent some of the facts that have to be accounted for by a proper syntactic theory of reflexivity. An attempt to develop such a theory within the framework of minimalist syntax is made in Oosthuizen (2013a, 2013b).

\section{References}

Abels, K. 2004. Right node raising: Ellipsis or across the board movement? In K. Moulton and M. Wolf (Eds.) Proceedings of NELS, 34. Amherst: GLSA University of Massachusetts pp. 45-59.

Adger, D. and G. Ramchand. 2003. Predication and equation. Linguistic Inquiry 34(3): 325-360.

Backhouse, R. 2014. An Analysis of the Grammatical Structure of Small Clauses in Afrikaans. A Minimalist Approach. Unpublished Master's thesis, University of Stellenbosch. 
Barbiers, S. and H. Bennis. s.a. Reflexives in dialects of Dutch. Ms. Syntactic Atlas of Dutch Dialects (SAND) project, Meertens Institute, Amsterdam.

Biberauer, T. 2008. Semi null-subject languages, expletives and expletive pro reconsidered. Occasional Papers in Linguistics 4: 1-45.

Bošković, Ź. 2004. Two notes on right node raising. University of Connecticut Working Papers in Linguistics 12: 13-24.

Bowers, J. 1997. A binary analysis of resultatives. In R. Blight and M. Moosally (Eds.) Texas Linguistic Forum 38: The syntax and semantics of predication. Austin, TX: Department of Linguistics, University of Texas. pp. 43-58.

Broekhuis, H., H. den Besten, K. Hoekstra and J. Rutten. 1995. Infinitival complementation in Dutch: On remnant extraposition. The Linguistic Review 12: 93-122.

Büring, D. 2005. Binding theory. Cambridge: Cambridge University Press.

Carnie, A. 2002. Syntax. A generative introduction. Oxford: Blackwell Publishing.

Chomsky, N. 1995. The minimalist program. Cambridge, MA: MIT Press.

Citko, B. 2008. Small clauses reconsidered: Not so small and not all alike. Lingua 118(3): 261-295.

Corver, N. 2003. A note on micro-dimensions of possession in Dutch and related languages. In J. Koster and H. van Riemsdijk (Eds.) Germania et alia: A linguistic Webschrift for Hans den Besten. Available online: http://odur.let.rug.nl/ koster/DenBesten/contents (Accessed 24 June 2012).

Corver, N. and M. van Koppen. 2010. Ellipsis in Dutch possessive noun phrases: A microcomparative approach. Journal of Comparative German Linguistics 13: 99-140.

Culicover, P. and R. Jackendoff. 2005. Simpler syntax. Oxford: Oxford University Press.

De Villiers, M. 1975. Die semantiek van Afrikaans. Kaapstad: HAUM.

De Vos, M. 2009. Afrikaans mixed adposition orders as a PF-linearization effect: Disharmony is a superficial side effect of deeper harmony. Available online: https://www.ru.ac.za/media/rhodesuniversity/content/englishlanguageandlinguistics/document s/markdocs/Devos-DRAFT-for-TADWO2009-Afrikaans_Adpositions.pdf (Accessed 26 January 2016).

Den Besten, H. 1978. Cases of possible syntactic interference in the development of Afrikaans. In P. Muysken (Ed.) Amsterdam Creole Studies II. Amsterdam: Instituut voor Algemene Taalwetenschap. pp. 5-56. 
Den Dikken, M. 2006. Realtors and linkers: The syntax of predication, predicate inversion and copulas. Cambridge, MA: MIT Press.

Fromkin. V. (Ed.) 2000. Linguistics: An introduction to linguistic theory. Oxford: Blackwell Publishing.

Goldberg, A. and R. Jackendoff. 2004. The English resultative as a family of constructions. Language 80: 532-568.

Gruber, J. 1965. Studies in Lexical Relations. Doctoral dissertation, MIT. Published as MIT Working Papers in Linguistics, GRUB01.

Haegeman, L. 1994. Introduction to government \& binding theory. Oxford: Blackwell Publishing.

Heinat, F. 2006a. Probes, Pronouns, and Binding in the Minimalist Program. Unpublished Doctoral dissertation, Lund University.

Heinat, F. 2006b. Probing phrases, pronouns, and binding. The Department of English: Working Papers in English Linguistics 6: 19-37.

Hoekstra, T. 1988. Small clause results. Lingua 74: 101-139.

Hopper, P. and E. Traugott. 1993. Grammaticalization. Cambridge: Cambridge University Press.

Kay, P. and C. Fillmore. 1999. Grammatical constructions and linguistic generalizations: The 'What's X Doing Y?' construction. Language 75(1): 1-33.

Keenan, E. 2009. Linguistic theory and the historical creation of English reflexives. In P. Crisma and G. Longobardi (Eds.) Historical syntax and linguistic theory. Oxford: Oxford University Press. pp. 41-57.

Levin, B. 1993. English verb classes and alternations: A preliminary investigation. Chicago: Chicago University Press.

McKoon, G. and T. Macfarland. 2000. Externally and internally caused change of state verbs. Language 76(4): 833-858.

Oosthuizen, J. 2000. Prepositions left and right in Afrikaans. Stellenbosch Papers in Linguistics 33: 67-90.

Oosthuizen, J. 2013a. Obligatory Reflexivity in Afrikaans. A Minimalist Approach. Unpublished Doctoral dissertation, University of Stellenbosch.

Oosthuizen, J. 2013b. Obligatory reflexivity in a minimalist grammar of Afrikaans. Stellenbosch Papers in Linguistics Plus 42: 205-241. 
Oosthuizen, J. and H. Waher. 1994. On the syntax of the se-construction in Afrikaans. Stellenbosch Papers in Linguistics 28: 21-44.

Ponelis, F. 1979. Afrikaanse sintaksis. Pretoria: J.L. van Schaik.

Postal, P. 1974. On raising: One rule of English grammar and its theoretical implications. Cambridge, MA: MIT Press.

Quirk, R., S. Greenbaum, G. Leech and J. Svartvik. 1985. A comprehensive grammar of the English language. London: Longman.

Radford, A. 2009. Analysing English sentences. A minimalist approach. Cambridge: Cambridge University Press.

Rappaport Hovav, M. and B. Levin. 2001. An event structure account of English resultatives. Language 77(4): 766-797.

Reinhart, T. and E. Reuland. 1993. Reflexivity. Linguistic Inquiry 24(4): 657-720.

Reuland, E. 2001. Primitives of binding. Linguistic Inquiry 32(3): 439-492.

Reuland, E. and M. Everaert. 2001. Deconstructing binding. In M. Baltin and C. Collins (Eds.) The handbook of contemporary syntactic theory. Oxford: Blackwell Publishing. pp. 634-669.

Rizzi, L. 2012. Core linguistic computations: How are they expressed in the mind/brain? Journal of Neurolinguistics 25(5): 489-499.

Sperber, D. and D. Wilson. 1995. Relevance. Communication and cognition. Oxford: Blackwell Publishing.

Van Schoor, J. 1983. Die grammatika van Standaard-Afrikaans. Cape Town: Lex Patria.

Walraven, T. 1975. The optional om in Dutch infinitive constructions. In A. Kraak (Ed.) Linguistics in the Netherlands 1972-1973. Assen: Van Gorcum. pp. 210-221.

Wechsler, S. 1997. Resultative predicates and control. In R. Blight and M. Moosally (Eds.) Texas Linguistic Forum 38: The syntax and semantics of predication. Austin, TX: Department of Linguistics, University of Texas. pp. 307-321.

Wee, L. and T. Ying. 2008. That's so last year! Constructions in a socio-cultural context. Journal of Pragmatics 40: 2100-2113.

Williams, A. 2008. Word order in resultatives. In C. Chang and H. Haynie (Eds.) Proceedings of the 26th West Coast Conference on Formal Linguistics. Somerville, MA: Cascadilla Proceedings Project. pp. 507-515.

Williams, E. 1980. Predication. Linguistic Inquiry 11(1): 203-238. 
Williams, E. 1983. Against small clauses. Linguistic Inquiry 14(2): 287-308.

Zwart, J.-W. 1997. Morphosyntax of verb movement. A minimalist approach to the syntax of Dutch. Dordrecht: Kluwer Academic Publishers.

Zwart, J.-W. 2002. Issues relating to a derivational theory of binding. In S. Epstein and T. Seely (Eds.) Derivation and explanation in the minimalist program. Oxford: Blackwell Publishing. pp. 268-304. 